\title{
Review of the phytochemical and pharmacological activities of Euphorbia hirta Linn.
}

\author{
Juveriyah Kausar', Durai Muthumani'2, Agaath Hedina', Sivasamy' ', Vijaya Anand' \\ 'Department of Human Genetics and Molecular Biology, Bharathiar University, Coimbatore-641 046, Tamil Nadu, INDIA. \\ 2Department of Biochemistry, Kanchi Shri Krishna College of Arts and Science, Kilambi, Kancheepuram-631 551, Tamil Nadu, INDIA.
}

\begin{abstract}
The use of plant extract to cure diseases has been the traditional way used in many parts of the world. The synthetic drugs used now are more prone to cause side effects than curing the disease. Hence, the use of plant extract has now emerged due to their effective action against the disease without causing any side effects. The plants belonging to the family called Euphorbia are widely used in medicine for its wide medicinal properties. The plant Euphorbia hirta has properties like anti-bacterial, anti-diarrheal, anti-allergic, diuretic, anti-oxidant, anti-tumor, anti-diabetic, anxiolytic and sedative activity. This review contains the detailed information about all the properties of E. hirta.
\end{abstract}

Key words: Euphorbia hirta, Anti-bacterial, Anti-oxidant, Diuretic, Sedative, Anti-apoptotic.

Corresponding author: Dr. A. Vijaya Anand,

Associate Professor and Head, Department of Human Genetics and Molecular Biology, Bharathiar University, Coimbatore-641 046, Tamil Nadu, INDIA. Mobile: +919842525830

E-mail: avamiet@yahoo.com DOI : $10.5530 /$ pj.2016.4.2

\section{INTRODUCTION}

Euphorbia hirta, belongs to genus Euphorbia, and family Euphorbiaceae. It is widely used as an important medicinal plant and used for the treatment of various diseases like gastrointestinal disorders including intestinal parasites, diarrhea, peptic ulcers, heartburn, vomiting, and amoebic dysentery, inflammations of the skin and mucous membranes like warts, scabies, tinea, thrush, aphthae, fungal afflictions, and measles and respiratory system disorders like asthma, bronchitis, hay fever, laryngeal spasms, emphysema, coughs, and cold. ${ }^{1,2}$ The plant is commonly found in China, India, Philippines, Australia, Africa, and Malaysia. According to the epidemiological survey, the increasing lifestyle in human causes more serious health issues like kidney and hepatic issues, which can be cured by the use of plant and weed extract. ${ }^{3}$

\section{BOTANICAL DESCRIPTION}

E. hirta is a plant that grows up to $80 \mathrm{~cm}$ in height with slender and erect stem. It is a broad leaf with hairy stem with leaves that are oblong, elliptical, opposite arrangement. It has a faint toothed margin with small flowers. The plant is usually found in grasslands, pathways, roadsides, and in areas rich in water. The fruits are yellow in color with 1-2 mm in diameter that has wrinkled seeds along the four sides with hairy capsules. ${ }^{2}$

\section{PHYTOCHEMISTRY}

E. hirta is composed of flavonoids, terpenoids, phenols, essential oil, and other compounds. Flavonoids include quercetin, quercitrin, quercitol, and its derivatives. ${ }^{4}$ Terpenoids include triterpenes: $\alpha$-amyrin, $\beta$-amyrin, friedelin, taraxerol, and its derivatives. ${ }^{4-6}$ Tannins include the dimer rich hydrolysable dehydro-ellagi-tannins-euphorbins A, B, C, E, and terchebin, the monomeric hydrolysable tannins-geraniin. ${ }^{7}$ Acids include ellagic, gallic, tannic, maleic and tartaric acid. ${ }^{7}$ Various other compounds present in the plant contain saponins, amino acids, alkaloids and minerals. ${ }^{8}$

The ethyl acetate extract of the plant contain afforded quercetrin, dimethoxy quercetrin, and two new prenylated flavonosides known as hirtacoumaroflavonoside and hirtaflavonoside- $\mathrm{B}$ characterized as 7-O(p-coumaroyl)-5,7,4'-trihydroxy-6-(3,3-dimethyl allyl)-flavonol-3-O- $\beta$-d-glucopyranosyl-(2" $\left.\rightarrow 1^{\prime \prime \prime}\right)$-O- $\alpha$-l-rhamnopyranoside and $5,7,3$, 4'-trihydroxy-6-(3, 3-dimethyl allyl)-8-(iso-butenyl)-flavonol-3-C- $\beta$-dglucopyranoside, respectively. All compounds extracted from the plant exhibited dose dependent inhibition of a-glucosidase. It was reported that 5,7,4'-trihydroxyflavone structure is imperative for the inhibitory activity. The rich flavonoids contents increase the potency and p-coumaroyl substitution at C-7 further enriched the a-glucosidase inhibition. ${ }^{9} \mathrm{~A}$ Study conducted by Yvette Fofie reported that the leaf and stem extract of $E$. hirta contained mineral salts, bioactive secondary metabolites and various other trace elements which can be used as a therapeutic drug against diabetes mellitus. ${ }^{10}$ Table 1 shows the different beneficial effects of different extracts of E. hirta.

\section{ANTI-BACTERIAL ACTIVITY}

The anti-bacterial activity of E. hirta was discovered and proven by using the methanol extract which showed the property against dysentery causing Shigella species in the Vero cell line. ${ }^{11}$ The non-cytotoxic concentration of the plant extract was examined for anti-bacterial activity against the various doses of the pathogen. The extracts were thus proved to be non-cytotoxic and effective anti-bacterial agents. ${ }^{11}$ The anti-microbial activity was tested using the nystatin and the methanol extract obtained from the leaves of E. hirta and examined on Candida albicans. The results obtained were favouring. ${ }^{12}$

It was reported that anti-microbial activity was attributed to tannins, flavonoids, alkaloids, glycosides, proteins, sterols, and saponins. The crude ethanolic extract of $E$. hirta exhibited anti-bacterial activity against the growth of Escherichia coli, Staphylococcus aureus, Pseudomonas aeruginosa, and Bacillus subtilis. ${ }^{13}$ When compared to the anti-bacterial activity of the plant extract between the gram positive and gram negative bacteria the results were exhibited more promisingly in gram positive bacteria. ${ }^{14}$ The plant is found to be rich with caffeic acid and epicatechin 3-gallate acid, which are found to be anti-bacterial in nature. This is the reason for the plant to be traditionally used in Malaysia for the treatment of gastrointestinal, respiratory and bronchial ailments caused by nosocomial infectious agents. The plant extract also expressed inhibitory action against $P$. aeruginosa cells. ${ }^{15}$ The flavonoids extracted from the roots of 
the plant expressed activity against $C$. albicans, Proteus mirabilis and $S$. aureus. ${ }^{16}$ Mir et al. ${ }^{17}$ conducted study on dengue patients whose platelet count was extremely low and after treatment with the plant extract it was found that $70 \%$ patients showed improvement in platelet count, fever and flu-like symptoms. ${ }^{17}$

\section{ANTI-DIARRHEAL ACTIVITY}

The aqueous extract obtained from the leaves of $E$. hirta exhibited excellent effect by decreasing the gastrointestinal motility in normal rats and effect of castor oil-induced diarrhea in mice. ${ }^{18}$ The anti-diarrheal activity was shown by Quercitin, a flavonoid extracted from the plant in crude form. ${ }^{19}$ This quercitin acts by increasing the colonic fluid absorption showing anti-diarrheal activity in the presence of secretagogue compounds. ${ }^{19}$

\section{ANTI-ALLERGIC ACTIVITY}

The ethanolic extract of $E$. hirta showed effective anti-anaphylactic activity. E. hirta by inhibits the passive cutaneous anaphylaxis in rat and active-paw and anaphylaxis in mice. The extracts of $E$. hirta showed suppressive effects on the release of tumor necrosis factor-alpha (TNF- $\alpha$ ) and interleuin-6 (IL-6) from anti-DNP-HAS activated rat peritoneal mast cells. Thus, it is reported that $E$. hirta is traditionally used as an herbal drug against Type I allergic disorders. ${ }^{20}$ It was also found that the aqueous extract of the plant inhibited the stimulation of prostaglandin E2 from activated rabbit synovial fluid cells, HIG-82 cells upto a large extent. Bioactive compounds possessing anti-inflammatory activity was reported to be highly concentrated in the aqueous extract of the plant. ${ }^{21}$

\section{DIURETIC ACTIVITY}

The ethanolic and aqueous leaf extracts of E. hirta showed diuresis in rats. It was observed that the extract increased urine output and electrolytes. ${ }^{22}$ Various experiments reported that the active components in the water extract of $E$. hirta leaf had similar property of diuretic just like acetazolamide thus proving the diuretic activity of E. hirta.

\section{ANTI-OXIDANT ACTIVITY}

The methanolic extract of the plant expressed similar anti-oxidant activity as that of green and black tea. ${ }^{23}$ The phenolic acids extracted from the aqueous leaf solution showed the anti-oxidant activity. Ferric reducing antioxidant power (FRAP) and 1,1-Diphenyl-2-picryl-hydrazyl (DPPH) assays were conducted to ascertain the efficacy of phenolic extracts. The phenolic acid from E. hirta displayed enhanced, free radical scavenging activity, and exhibited protection against oxidative damage to protein. ${ }^{23}$ Lipid peroxides, hydroperoxides and both enzymatic and non-enzymatic anti-oxidants express the anti-oxidant potential of the leaf extract. ${ }^{24}$

\section{ANTI-TUMOR ACTIVITY}

The anti-tumor activity of the E. hirta extract was studied on EL-4 cell lines in Swiss Albino mice. Significant in cell tumor mass was observed after treating it with the plant extract. ${ }^{25}$ The methanol extract of the leaves of $E$. hirta showed anti-proliferative activity on Hep-2 cells from human epithelioma of the larynx. ${ }^{26}$ It was also evaluated that the methanolic extract and quercetin exhibited mutagenic and anti-mutagenic activity. ${ }^{27}$

\section{ANTI-APOPTOTIC ACTIVITY}

In the studies conducted by Kwan et al. ${ }^{28}$ it was revealed that E. hirta showed significant inhibition of the survival of breast cancer cell lines MCF-7 cells and the half inhibitory concentration $\left(\mathrm{IC}_{50}\right)$ values were $25.26 \mu \mathrm{g} / \mathrm{mL}$ at $24 \mathrm{~h}$. Microscopic studies conducted expressed that
E. hirta treated cells showed remarkable morphological characteristics of apoptosis. E. hirta extract also expressed an ignorable influence on the lactate dehydrogenase leakage. The flow cytometry study confirmed that E. hirta extract induced apoptosis in MCF-7 cells. E. hirta also induced DNA fragmentation in MCF-7 cells. Above all, E. hirta treatment resulted in the accumulation of cells at the $S$ and $G_{2} / M$ phases and apoptosis. ${ }^{28}$

\section{ANTI-DIABETIC ACTIVITY}

Ethanolic and ethyl acetate extracts of $E$. hirta were used to examine the anti-diabetic activity. Using the a-glusocidase inhibitor method the extract was assayed in vitro. A significant reduction in the blood glucose level was observed in streptozotocin induced diabetic mice on treatment with ethanolic extract of leaf, flower and stem of the plant. ${ }^{29}$ Subramanian et al. ${ }^{24}$ treated the experimental diabetic rats with the leaf extract of E. hirta and found the anti-diabetic property of the extract. ${ }^{24}$

\section{ANXIOLYTIC AND SEDATIVE ACTIVITY}

The hydroalcoholic extract of E. hirta was used to examine anxiolytic property of the plant in chronically stressed rats. To evaluate the mechanism for the anxiolytic action of the drug, antagonists of the GABAA receptor-benzodiazepine receptor- $\mathrm{Cl}$ channel complex with E. hirta were used together, showed marked anti-anxiety activity in chronic immobilization stress. ${ }^{30}$

\section{ANTI-VENOM ACTIVITY}

It is reported that the methanolic extract of E. hirta inhibited the venom enzymes under the in vitro conditions, thereby reducing the ration of edema in the mice. The evidences were collected by the histopathological analysis of the vital organs. The content of phenolic compound was also found to be quite elevated and the plant was found to be highly rich with the contents of ellagic acid, quinic acid and gallic acid. These compounds well known for their ability to inhibit venom proteases. ${ }^{31}$

\section{IMMUNOSTIMULATORY ACTIVITY}

Pratheepa and Sukumaran ${ }^{32}$ worked with the leaf extract of $E$. hirta with the objective of studying its immunostimulatory activity. The study was conducted on a medicated fish which was infected with Aeromonas hydrophila pathogen. It was reported by them that the count of red blood cells and white blood cells gradually increased with the higher dose concentration of the plant leaf extract. The leaf extract was also able to induce immune response of antibodies. The extract also helped in the elimination of pathogens from the kidney and blood of the fish. Thus, their work suggested that $E$. hirta possessed immunostimulatory activity by stimulating both specific and non-specific immunity at elevated concentrations. ${ }^{32}$

\section{WOUND HEALING ACTIVITY}

Studies conducted by Upadhyay et al. ${ }^{33}$ reveals that the methanol extract of the E. hirta possess wound healing activity as it showed potentially high anti-microbial activity against Escherichia coli and Klebsiella pneumoniae along with the fibroblast proliferating activity. In their study, they concluded that the wound healing activity and collagen production in wounded tissues is governed by the Smad-mediated proteins. ${ }^{33}$ The triterpenes extracted from the stems, roots and leaves of $E$. hirta showed anti-microbial activity and are commonly used for wound healing and for the treatment of boils. ${ }^{34}$

\section{ANTI-INFLAMMATORY ACTIVITY}

Ahmad et al. ${ }^{35}$ worked with the plant extract whose traditional use for the treatment of a variety of diseases drove their interest to check for the anti-inflammatory effect of it. They initiated the study with the aim 
Table 1 Shows the several of activities of Euphorbia hirta

\begin{tabular}{|c|c|c|}
\hline Activity & Action & Study done by \\
\hline Anti-bacterial activity & $\begin{array}{l}\text { Plant extracts were used to check } \\
\text { the anti-bacterial activity in } \\
\text { Escherichia coli, Staphylococcus } \\
\text { aureus, Pseudomonas. aeruginosa, } \\
\text { and Bacillus subtilis and the results } \\
\text { showed reduced growth of these } \\
\text { bacteria. }\end{array}$ & $\begin{array}{l}\text { Vijaya et al., } 1995 \\
\text { Jackson et al., } 2009 \\
\text { Suresh et al., } 2008 \\
\text { Ogbulie et al., } 2007 \\
\text { Nelofar et al., } 2006\end{array}$ \\
\hline Anti-diarrheal activity & $\begin{array}{l}\text { The flavonoid called quercitin } \\
\text { present in the leaf extract showed } \\
\text { anti-diarrheal activity by increasing } \\
\text { the colonic fluid absorption in the } \\
\text { presence of secretagogue compounds }\end{array}$ & $\begin{array}{c}\text { Galvez et al., } 1993 \\
\text { Hore et al., } 2006\end{array}$ \\
\hline Anti-allergic activity & $\begin{array}{l}\text { The ethanolic extract of E. hirta show } \\
\text { suppressive effects on the release of } \\
\text { TNF- } \alpha \text { and IL-6 from anti-DNP-HAS } \\
\text { activated rat peritoneal mast cells thus } \\
\text { act as an anti-allergic agent. }\end{array}$ & Youssouf et al., 2007 \\
\hline Diuretic activity & $\begin{array}{l}\text { The ethanolic extract when given to } \\
\text { rat showed increased urine output } \\
\text { thus enhancing the diuresis. }\end{array}$ & Johnson et al., 1999 \\
\hline Anti-oxidant activity & $\begin{array}{l}\text { The methanolic extract showed the } \\
\text { anti-oxidant activity. The FRAP and } \\
\text { DPPH assays proved the activity of E. } \\
\text { hirta extract acting against oxidative } \\
\text { damage to protein. }\end{array}$ & Sharma and Prasad 2008 \\
\hline Anti-tumor activity & $\begin{array}{l}\text { The methanol extract of the leaves } \\
\text { of E. hirta showed anti-proliferative } \\
\text { activity on Hep- } 2 \text { cells from human } \\
\text { epithelioma of the larynx thus } \\
\text { proving its anti-tumor activity. }\end{array}$ & $\begin{array}{l}\text { Sandeep and Chandrakant, } 2011 \\
\text { Brindha et al., } 2010 \\
\text { Daphne et al., } 2009\end{array}$ \\
\hline Anti-diabetic activity & $\begin{array}{l}\text { Reduction in the blood glucose } \\
\text { level was observed in streptozotocin } \\
\text { induced diabetic mice on treatment } \\
\text { with ethanolic extract of leaf, flower } \\
\text { and stem of the plant }\end{array}$ & Widharna et al., 2010 \\
\hline Anxiolytic and sedative activity & $\begin{array}{l}\text { The antagonists of the GABAA } \\
\text { receptor-benzodiazepine receptor-Cl } \\
\text { channel complex with E. hirta were } \\
\text { used together, and anxiety in the EPM } \\
\text { showed marked anti-anxiety activity } \\
\text { in chronic immobilization stress }\end{array}$ & Anuradha et al., 2008 \\
\hline
\end{tabular}

of determining the anti-arthritic effects of $E$. hirta in the mouse models which were the adjuvant of arthritis. The effect of the plant extract was studied on the pro-inflammatory and anti-inflammatory cytokines. A substantial decrease was seen in the level of pro-inflammatory cytokines and an up-regulated anti-inflammatory cytokine effect was recorded. Thus, E. hirta is regarded as a promising treatment for arthritis and other inflammatory diseases. ${ }^{35}$

\section{TOXICITY STUDIES}

E. hirta is widely used as ethnomedicine due to its various benefits. Thus, the need of toxicity, check arose in the mind of various researchers and Yuet Ping et al. ${ }^{36}$ went ahead with it. The conducted the study for evaluation of acute and subchronic toxicity on Sprague Dawley rats. The extract dose did not express any signs of acute toxicity or mortality on any of the rats. Long term oral administration of the plant extract showed no varia- tion in the food or water consumption, body weight, biochemical and haemotological parameters etc. therefore, the team concluded that the plant extract does not possess acute or sub-chronic toxicity. ${ }^{36}$

\section{CONCLUSION}

In this review of E. hirta, a summary of its phytochemistry, anti-bacterial activity, anti-diarrheal activity, anti-allergic activity, diuretic activity, anti-oxidant activity, anti-tumor activity, anti-diabetic activity, anxiolytic and sedative activity were discussed in detail. Details furnished in this review will further help in exploring more about other properties associated with it.

\section{CONFLICTS OF INTEREST}

No funding source and there is no conflict of interest. 


\section{ABBREVIATION USED}

DPPH: 1,1-Diphenyl-2-picryl-hydrazyl; FRAP: Ferric Reducing Antioxidant Potential; IC $_{50}$ : Inhibitory Concentration; IL-6: Interleukin-6; TNF- $\boldsymbol{\alpha}$ : Tumor Necrosis Factor-Alpha.

\section{REFERENCES}

1. Zhongyao da ci dian. Shanghai Sci-tech Press.1986;139.

2. Zhonghua ben cao. Shanghai Sci-tech Press.1999;4:788.

3. Manoharan T, Sampathkumar P, Dheeba B, Sheikabdulla S, Vinothprasanna G, Vinothkannan $\mathrm{R}$, et al. Potential hepatoprotecetive effect of aqueous extract of Gracilaria corticata in AFB1 induced hepatotoxicity in Wistar rats. Journal of biological sciences. 2008;8(8):1352-55

4. Yan SJ, Ye DW, Wang Y. Ent-Kaurane Diterpenoids from Euphorbia hirta, Rec Nat Prod. 2011;5(4):247-25

5. Hazimi A, Mohammad H, Sarra A. Jolkinolidediterpenoids and other constituents from Euphorbia hirta. J Saudi Chem Soc. 2008;12:87-93

6. Baslas RK, Agarwal R. Isolation and characterization of different constituents of Euphorbia hirta Linn. Curr Sci. 1980;49:311-2.

7. Ogunlesi M, Okiei W, Ofor E. Analysis of the essential oil from the dried leaves of Euphorbia hirta Linn (Euphorbiaceae), a potential medication for asthma. Afr J Biotechnol. 2009;8(24):7042-50.

8. Mallavadhani UV, Narasimhan K. Two novel butanolrhamno sides from an Indian traditional herb, Euphorbia hirta. Nat Prod Res. 2009;23(7):644-51.

9. Sheliya MA, Rayhana B, Ali A, Pillai KK, Aeri V, Sharma M, Mir SR. Inhibition of $\alpha$-glucosidase by prenylated flavonoids from Euphorbia hirta L. herb. J ethnopharmacol. 2015;8:1-14.

10. Yvette Fofie NB, Sanogo R, Coulibaly K, Kone-Bamba D. Minerals salt composition and secondary metabolites of Euphorbia hirta L., an anti-hyperglycemic plant. Pharmacognosy. 2015;7(1):7-13.

11. Vijaya K, Ananthan S, Nalinib R. Anti-bacterial effect of theaflavin, polyphenon 60 (Camelliasinensis) and Euphorbia hirta on Shigella spp.-a cell culture study. J Ethnophannacol. 1995;49(2):115-8.

12. Jackson C, Agboke A, Nwoke V. In vitro evaluation of anti-microbial activity of combinations of nystatin and Euphorbia hirta leaf extract against Candida albicans by the checkerboard method. J Med Plants Res. 2009;3(9):666-9.

13. Ogbulie JN, Ogueke CC, Okoli IC, Anyanwu BN. Anti-bacterial activities and toxicological potentials of crude ethanolic extracts of Euphorbia hirta. Afr J Biotechnol. 2007;6(13):1544-8.

14. Nelofar A, Suhail T, Ahmad S, Evaluation of anti-bacterial activity of a locally available medicinal plant Euphorbia hirta, J Chem Soc Pak. 2006;28(6):623-6.

15. Perumal S, Mahmud R, Ramanathan S. Anti-infective potential of caffeic acid and epicatechin 3-gallate isolated from methanol extract of Euphorbia hirta L. against Pseudomonas aeruginosa. Nat Prod Res. 2015;29(18):176,6-9.

16. Singh G, Kumar P. Phytochemical study and screening for anti-microbial activity of flavonoids of Euphorbia hirta. Asian Pac J Trop Biomed. 2013;9(69):2-6.

17. Mir M, Khurshid R, Aftab R. Management of thrombocytopenia and flu-like symptoms in dengue patients with herbal water of Euphorbia hirta. Molecules. 2012;7(77):82-91.

18. Hore SK, Ahuja V, Mehta G, Effect of aqueous Euphorbia hirta leaf extract on gastrointestinal motility, Fitoterapia. 2006;77(1):35-8

19. Galvez J, Crespo ME, Jimenez J, Suarez A, Zarzuelo A, Anti-diarrheic activity of quercitrin in mice and rats. J Pharm Pharmacol. 1993;45(2):157.

20. Youssouf MS, Kaiser P, Tahir M, Anti-anaphylactic effect of Euphorbia hirta. Fitoterapia. 2007;78(7-8):535-9.

21. Chen J, Er HM. Mohamed SM, Chen YS. In vitro anti-inflammatory activity of fractionated Euphorbia hirta aqueous extract on rabbit synovial fibroblasts. Pharmacognosy Res. 2015;1:7-13.

22. Johnson PB, Abdurahman EM, Tiam EA, Abdu-Aguye I, Hussaini IM, Euphorbia hirta leaf extracts increase urine output and electrolytes in rats. J Ethnopharmacol. 1999;65(1):63-9.

23. Sharma NK, Prasad R, Oxidative injury to protein and their protection by phenolic acid anti-oxidants from Euphorbia hirta leaves Abstracts. J Biotechnol. 2008;136:717-42.

24. Subramanian SP, Bhuwaneshwari S, Prasath GS. Anti-diabetic and anti-oxidant potentials of Euphorbia hirta leaves extract studied in streptozotocin- induced experimental diabetes in rats. Asian Pac J Trop Med. 2011;5:386-90.

25. Sandeep BP, Chandrakant SM. Phytochemical investigation and anti-tumour ac tivity of Euphorbia hirta Linn. Eur J Exp Biol. 2011;1(1):51-6.

26. Brindha D, Saroja S, Jeyanthi GP, Protective potential (correction of potencial) of Euphorbia hirta against cytotoxicity induced in hepatocytes and a HepG2 cel line. J Basic Clin Physiol Pharmacol. 2010;21(4):401-13.

27. Daphne SYL, Hui ME, Yu SC, Mutagenic and anti-mutagenic activities of aqueous and methanol extracts of Euphorbia hirta. J Ethnopharmacol. 2009;126:406-14

28. Kwan YP, Saito T, Ibrahim D, Al-Hassan FM, Ein Oon C, Chen Y, et al. Evaluation of cytotoxicity, cell-cycle arrest and apoptotic induction by Euphorbia hirta in MCF-7 breast cancer cells. J Ethnopharmacol. 2015;165:180-90.

29. Widharna RM, Soemardji AA, Wirasutisna KR, KardonoL BS. Anti-diabetes mellitus activity in vivo of ethanolic extract and ethyl acetate fraction of Euphorbia hirta L. herb international. J Pharmacol. 2010;6(3):231-40.

30. Anuradha H, Srikumar BN, Shankaranarayana RBS, Lakshmana M. Euphorbia hirta reverses chronic stress-induced anxiety and mediates its action through the GABAA receptor benzodiazepine receptor-Cl2 channel complex. J Neura Transm. 2008;115(1):35-42.

31. Gopi K, Renu K, Sannanaik Vishwanath B, Jayaraman G. protective effects of Euphorbia hirta and its components against snake venom induced lethality. Biomed J. 2015:4:301-6.

32. Pratheepa $V$, Sukumaran N. Effect of Euphorbia hirta plant leaf extract on immunostimmulant response of Aeromonas hydrophilia infected Cyprinus caprio. Pharmacogn Mag. 2014;3:534-42.

33. Upadhyay A, Chattopadhyay P, Goyary D, Mazumder PM, Veer V. Euphorbia hirta accelerates fibroblast proliferation and smad-mediated collagen production in rat excision wound. Molecules. 2014;9:14567-81.

34. Ragasa CY, Cornelio KB. Triterpenes from Euphorbia hirta and their cytotoxicity. Exp Ther Med. 2013;5:1247-50.

35. Ahmad SF, Attia SM, Bakheet SA, Ashour AE, Zoheir KM, Abd-Allah AR. Antiinflammatory effect of Euphorbia hirta in an adjuvant induced arthritic murine model. Biomed Res Int. 2013;182064.

36. Yuet Ping K, Darah I, Chen Y, Sreeramanan S, Sasidharan S. acute and subchronic toxicity study of Euphorbia hirta L. methanol extract in rats. Chin J Nat Med. 2013;5:528-33.
PICTORIAL ABSTRACT

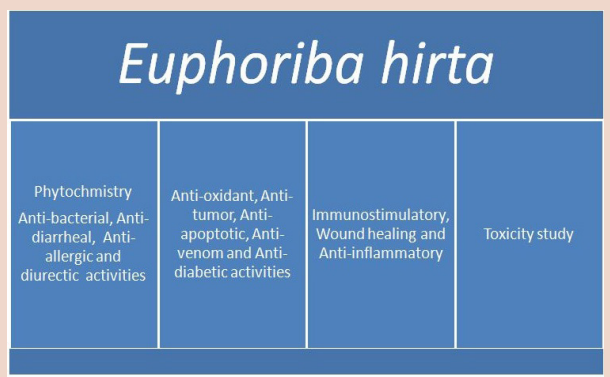

\section{SUMMARY}

- Euphorbia hirta has been recognized as the medicinally essential phytoconstituents.

- These phytoconstituents have immense potential of this plant in the treatment of numerous diseases.

\section{ABOUT AUTHOR}

Dr. A. Vijaya Anand: Associate Professor and Head, Department of Human Genetics and Molecular Biology, Bharathiar University, Coimbatore, Tamil Nadu, India. He has published multiple scientific articles in international journals. He is currently engaged in the field of phytopharmacology, neurogenetics, medical genetics and clinical biochemistry. 